\title{
Finding Ways to Attract Clients: A Content Analysis of Japanese Language Tutors' Ads in an Online Tutor Marketplace
}

\author{
Aditya Nur Patria \\ Universitas Diponegoro, J1. Prof. Sudarto No.13, Tembalang, Semarang 50275, Indonesia \\ *Corresponding Author. Tel +62-858-067-44-000; Fax +62-24-7465404 \\ Email: anpatria@lecturer.undip.ac.id
}

\begin{abstract}
The growing number of freelance marketplaces allows students to earn extra money as tutors. The hypercompetitive nature in the marketplaces forces students to compete with non-student tutors in order to get clients (Popiel, 2017). Non-student tutors may be better equipped with a lot of experiences. However, all freelance tutors need to post impressive ads to get their clients, particularly in a niche subject such as Japanese language. The present study explores the differences of information put in ads between student tutors and non-student tutors on a tutor marketplace, Superprof. Content analysis (Cohen et al, 2011) was used to identify categories of information in the ads. The results show that there were 11 categories of information including tutors' name, origin, current employment status, education background, language proficiency certificate, course level, course type, rhetoric, experience in Japan, coverage area, and availability. The data were then analyzed statistically to find the categories of information with a significant difference. It shows that both groups have difference in putting information related to their current employment status $(t=3.88, p<0.001, d=1.05)$ and their education background $(t=2.78, p<0.005, d=0.75)$. The implication of the study is that student tutors tend to value their relationship with academic institutions and make it as a bargaining power to market their skills in the marketplace.
\end{abstract}

Keywords: ads; content analysis,;freelance,;Japanese language tutors; marketplaces

\section{Introduction}

The development of digitalization in Indonesia enables people to do many things in real life through the internet. From the ease of good delivery, online showcases of various products, raid-hailing services to booking private tutors, Indonesians enjoy the privilege of growing ecosystems of digital companies across the nation (Asian Development Bank, 2020). The progressive development of digital technologies undeniably contributes to the change in people's lifestyle, especially those who have internet access (Gere, 2008; Miller, 2011). The change is also reflected in the way people find jobs or clients these days. In the past, job ads on newspaper could be the mainstream way to look for a job or to find clients for one's business. Although job ads on newspaper are not simply abandoned, there is a growing tendency to look for a job online thanks to the emergence of employment websites and online freelance marketplaces. People can freely access the websites anytime and anywhere from their devices without any subscription required.

Online freelance marketplaces provide a space for gig economy to thrive. Gig economy is a market system in which people market themselves, whether as unskilled labors or as skilled professionals (Green, Walker, Alabulththim, Smith, \& Phillips, 2018). This market system is characterized by the competitive labor market, direct contract with clients, and no responsibility from clients and online platforms regarding ones' working condition (Woodcock \& Graham, 2020). Online freelance marketplaces are growing quite rapidly not only due to the advancement of technology but also the 
preference of flexible working hours among younger generation (Hershatter \& Epstein, 2010; PricewaterhouseCoopers, 2011). With the flexible working hours, ones have more freedom to manage their time to do their activities. Freelance marketplace websites work as a platform that let freelancers meet their clients across the globe (Popiel, 2017). Freelancers put their ads on the website for free. Then, prospective clients can pick which freelancers' skills meet their needs. The clients can contact the freelancers by creating an account on the platform. This is used to protect the private information of the freelancers. The myriad number of freelancers in the marketplaces cause the emergence of hyper-competition among them. Hence, people should be more aware on how to brand themselves in a more efficient way (Andersen, 2018; Gandini, 2016). This involves presenting themselves with relevant information to their fields of expertise.

Among the most popular freelance job in online freelance marketplaces is giving private tuition. This freelance job allows people to share their knowledge in a particular field regardless their current occupations. At the same time, service buyers have benefited from the platform to find tutors with a niche area of expertise such as Japanese language. In Semarang, Indonesia, Japanese language is offered at a small number of institutions. This limits the access for general public interested in the language to learn it. Hence, the online freelance marketplaces play an important role to bridge Japanese language tutors and prospective tutees. In order to succeed in getting tutees or clients, tutors need to market themselves. However, they may need to be careful about the information they put on their ads. This is because they are required not only to make their ads appealing to target audiences but also to maintain their persona as educators.
Several global players of freelance marketplaces can be readily accessed in Indonesia. One of freelance marketplace websites which specifically target tutors is Superprof. According to its 'About' page ("Tentang kami," n.d.), the website was founded in France, August 2013. Around 5 years after its establishment, the freelance tutor marketplace entered Indonesia market. To date, the website has over 15 million tutors registered on the marketplace worldwide with 1001 subjects offered. This website allows tutors to market themselves and meet their prospective tutees. In marketing themselves, they can display their expected fees for a teaching session. The fees are usually negotiable depending on the number of students and the distance, in case the session is offline. In addition to ads section, the website provides some space for tutors to explain their teaching methods and background. In "teaching method" section, tutors can explain how they will teach their tutees and what books or learning materials they will use during the tuition. The "background" section allows the tutors to explain about their areas of expertise, education backgrounds, work experiences, and relevant information related to themselves.

The present study would like to explore the ads put by tutors in Semarang on a freelance marketplace website, Superprof. Provided that student tutors need to compete with non-student tutors who are likely more experienced, it is crucial to understand the messages they put in the ads. The present study is expected to give both theoretical and practical contributions to the discourses of Japanese language teachers, particularly on a freelance marketplace.

In this study, content analysis is used as a tool to investigate the ads put on the tutor marketplace website. According to Cohen, Manion, and Morrison (2011, p.475), content analysis is a "process of 
summarizing and reporting written data the main contents of data and their messages." It allows the researcher to categorize information in the document. Hence, this makes the identification of information types provided in the ads easier. In content analysis, texts are treated as any types of writing which are intended to be read, interpreted, and understood by general audience (Krippendorp, 2004). This allows the researcher to investigate written texts available in any platforms, not necessarily in printed ones. Thus, job ads can be analyzed using this tool of analysis.

As content analysis attempts to understand texts by dissecting it into categories of information, some steps need to be undertaken in order to obtain more accurate and comprehensive results. Some scholars (e.g., Cohen et al., 2011; Ezzy, 2002; Wang \& Li, 2020) suggest that content analysis involves some research procedures, including categorizing, comparing, and concluding. The final step was to draw theoretical conclusion from the analysis object, i.e., texts. Anderson and Arsenault (1998) have also suggested that quantitative measurement may enrich content analysis.

In brief, the present study attempts to answer the following question:

1. How similar or different are the ads of student tutors compared to those of nonstudent tutors in a freelance marketplace website?

Thus, the objective of the study is as follow.

1. To understand the similarities and differences of information in ads by student tutors and non-student tutors in a freelance marketplace website.

It should be noted that the present study focuses only on the language content of the ads. Thus, the profile pictures used by tutors in their ads are not included in the analysis.

\section{Methods}

The present study uses content analysis incorporated with quantitative data analysis. Content analysis is a tool of analysis which allows the researcher to summarize the information in the data (Cohen et al, 2011). While content analysis facilitates the researcher with the ability to grasp the themes emerging in the texts, quantitative data analysis allows the researcher to draw a general conclusion from a larger sample size than qualitative data analysis does (Rahman, 2017). These will be very useful in the investigation of job ads.

\subsection{Data Collection and Analysis}

The data investigated in the present study are obtained from Superprof, a freelance tutor marketplace website. The data are the ads posted by tutors registered in the website. The linguistic data are publicly accessible without any need to create an account beforehand. In order to limit the abundant amount of the data, the present study focuses on the ads posted by Japanese language tutors in Semarang. The procedures of data collection are as follows.

\section{The research visited superprof.co.id}

2. In the search bar on the homepage, the researcher typed "Bahasa Jepang" (Japanese language) and chose "Semarang" as the city area.

3. After clicking the button "Temukan seorang guru" (Find a tutor), the researcher received 57 search results.

4. The search results displayed information about each tutor including their name, ads, and profile photos. 
Tersedia online di http://ejournal.undip.ac.id/index.php/kiryoku

5. The researcher then collected the ads consisting of linguistic data only.

In addition to the linguistic data of the ads, the researcher also collected information about each tutor, particularly with regard to their employment status, whether they are students or non-students. This information is used to group the data in accordance with the objectives of the research. There are 25 student tutors and 32 non-student tutors. After obtaining the job ads, the researcher read ads carefully and categorized the information in each ads. Some categories of information present in the linguistic data of the job ads are presented in table one.

\begin{tabular}{|c|c|}
\hline Categories & Description \\
\hline Name & $\begin{array}{l}\text { Name of the tutors or the brand } \\
\text { of the tuition }\end{array}$ \\
\hline Origin & $\begin{array}{l}\text { Origin of the tutors } \\
\text { e.g. Jakartans, ... berasal dari } \\
\text { Semarang (originated from } \\
\text { Semarang) }\end{array}$ \\
\hline $\begin{array}{l}\text { Current } \\
\text { (employment) status }\end{array}$ & $\begin{array}{l}\text { Employment status of the } \\
\text { tutors, including students } \\
\text { e.g. Fresh graduate, Pengajar } \\
\text { (tutor) }\end{array}$ \\
\hline \multirow[t]{2}{*}{$\begin{array}{l}\text { Education } \\
\text { background }\end{array}$} & $\begin{array}{l}\text { School or university } \\
\text { affiliations or other education } \\
\text { backgrounds }\end{array}$ \\
\hline & $\begin{array}{ll}\text { e.g. ... lulusan pendidikan } \\
\text { bahasa Jepang (a graduate } \\
\text { from Japanese language } \\
\text { education major) }\end{array}$ \\
\hline \multirow[t]{2}{*}{$\begin{array}{l}\text { Language } \\
\text { proficiency } \\
\text { certificate }\end{array}$} & $\begin{array}{l}\text { Certificates } \begin{array}{r}\text { indicating } \\
\text { language }\end{array} \\
\text { achievement, such as N1, N2, } \\
\mathrm{N} 3, \mathrm{~N} 4 \text {, and N5 certificates or } \\
\text { Japanese language competition } \\
\text { certificates }\end{array}$ \\
\hline & $\begin{array}{l}\text { e.g., ... bersertifikat N2 } \\
\text { (obtained an N2 certificate) }\end{array}$ \\
\hline Course level & $\begin{array}{l}\text { Levels of Japanese language } \\
\text { course offered or level of target } \\
\text { tutees } \\
\text { e.g. ... untuk siswa/mahasiswa } \\
\text { (for school/university students) }\end{array}$ \\
\hline Course type & $\begin{array}{l}\text { Types of Japanese language } \\
\text { course offered, or type of } \\
\text { courses offered } \\
\text { e.g. ... les kursus privat bahasa } \\
\text { Jepang (Japanese language } \\
\text { private tuition) }\end{array}$ \\
\hline
\end{tabular}

\begin{tabular}{|c|c|}
\hline Rhetoric & $\begin{array}{l}\text { Persuasive language styles } \\
\text { including invitation, positive } \\
\text { adjectives } \\
\text { e.g. Mari belajar dengan } \\
\text { happy (Let's learn with } \\
\text { happiness) }\end{array}$ \\
\hline Experience in Japan & $\begin{array}{l}\text { Experiences of living or } \\
\text { working in Japan or Japanese } \\
\text { companies } \\
\text { e.g. ... pernah tinggal di } \\
\text { Jepang (once lived in Japan) }\end{array}$ \\
\hline Coverage area & $\begin{array}{l}\text { Areas which the tutors can } \\
\text { reach for offline tuition } \\
\text { e.g. ... privat di Semarang dan } \\
\text { sekitarnya (tuition in } \\
\begin{array}{l}\text { Semarang and } \\
\text { neighborhood) }\end{array}\end{array}$ \\
\hline Availability & $\begin{array}{l}\text { Time availability of the tutors } \\
\text { e.g. ... di atas jam } 4 \text { sore (after } \\
\text { 4 P.M.) }\end{array}$ \\
\hline
\end{tabular}

$\overline{\text { Table 1: Categories of information based on ads }}$

After categorizing the information in the ads, the researcher divided the tutors into two groups i.e., student tutors and nonstudent tutors. Furthermore, the researcher coded the presence of each information category in each ads. Score 1 if the information is present in the ads. Score 0 if the information is absent in the ads. The interval data were analyzed using independent t-test in SPSS Statistics version 28. Furthermore, the effect size was computed using effect size calculator on http://www.uccs.edu/ lbecker/.

\section{Results and Discussion 3.1. Results}

Based on the descriptive statistics in table two, the ads of student tutors and nonstudent tutors are relatively similar across the nine categories of information. It is obvious from the mean value of each type of information between the two groups which are equally similar. For instance, the mean values of information related to name are nearly identical, 0.12 for student tutors' ads and 0.13 for non-student tutors' ads. The information of name is rarely found in the ads. Nevertheless, the results of t-test show that there are two categories of information between the two groups which 
have a significant difference. The significant differences between both can be seen in the presence of information regarding the tutors' current employment status $(t=3.88, p<0.001, d=1.05)$ and their education background $(t=2.78, p<$ $0.005, d=0.75)$. The mean values of the two categories indicate that more student tutors use these two categories than nonstudent tutors do.

\begin{tabular}{|c|c|c|c|c|c|}
\hline & & & & & \\
\hline & Mean & $S D$ & Mean & $S D$ & $t$ \\
\hline 1. Name & .12 & .33 & .13 & .18 & 1.30 \\
\hline 2. Origin & .04 & .20 & .03 & .18 & .17 \\
\hline $\begin{array}{l}\text { 3. Current } \\
\text { employment } \\
\text { status }\end{array}$ & .68 & .48 & .22 & .42 & $3.88 * *$ \\
\hline $\begin{array}{l}\text { 4. Education } \\
\text { background }\end{array}$ & .56 & .51 & .22 & .42 & $2.78 *$ \\
\hline $\begin{array}{l}\text { 5. Language } \\
\text { proficiency } \\
\text { certificate }\end{array}$ & .16 & .37 & .16 & .37 & .038 \\
\hline $\begin{array}{l}\text { 6. Course } \\
\text { level }\end{array}$ & .36 & .49 & .50 & .51 & -1.05 \\
\hline 7. Course type & .28 & .46 & .41 & .50 & -.982 \\
\hline 8. Rhetoric & .60 & .50 & .59 & .50 & .047 \\
\hline $\begin{array}{l}\text { 9. Experience } \\
\text { in Japan }\end{array}$ & .12 & .33 & .19 & .40 & -.684 \\
\hline $\begin{array}{l}10 . \text { Coverage } \\
\text { area }\end{array}$ & .28 & .46 & .25 & .44 & .251 \\
\hline $\begin{array}{l}11 . \\
\text { Availability }\end{array}$ & .08 & .28 & .03 & .18 & .808 \\
\hline
\end{tabular}

Table 2: Comparison of information on student tutors' and non-student tutors' ads

Note. $* p<0.005, * * p<0.001, S D=$ Standard Deviation

\subsection{Discussion}

Based on the results of the statistical analysis, student tutors and non-student tutors have different perceptions on the inclusion of information related to current employment status and education background. The employment status in the present study involves tutors' status as students. It is likely that student tutors make use of their relationship with academic institutions to legitimate their abilities in teaching Japanese language. As they introduce themselves as students, they also include the information about their education background, either their universities or majors. Both categories of information apparently are more valued among the student tutors as a bargaining power to offer their services of Japanese language tuition to the students. It is important to note that non-student tutors, despite their experience or current employment status, do not put their job position in the ads. It is likely that the nonstudent tutors prefer putting the information about their current employment status in the "background" section rather than in the ads. The non-student tutors in the present study have various job positions, including Japanese language teachers at language institutions, sailors, company employees, and many more. It is possible that their avoidance in revealing their current employment status because it is not relevant with the tuition, which tend be related to academic activities or any Japanese related activities. As Andersen (2018) mentioned, strategic information in resume will attract the clients better than the number of redundant experiences. However, the data of the present study are insufficient to draw a solid conclusion on why the non-student tutors avoid putting their current employment status in the ads.

Regarding the minimal use of information related to name and origin, it seems that all tutors have agreed that the information may be redundant in the ads. The earlier is already available on the profile. The latter is apparently irrelevant with the goal of the tuition. Interestingly, 
some tutors still include information about their coverage areas or areas which they can reach for offline tuition although the location have been displayed on their profile alongside with their photos and names. Both student tutors and non-student tutors equally agree with the importance of rhetoric in their ads. More than half of people in the groups make use of the rhetoric to attract their prospective tutees. It should be noted that some rhetoric in the ads include positive adjectives which may boost their positive personas. It is necessary to present ones' self in a way desirable to the clients to succeed in such a hypercompetitive environment (Gandini, 2016; Popiel, 2017; Woodcock \& Graham, 2020).

\section{Conclusion}

The present study seeks to answer the different information put by student tutors and non-student tutors on their ads in a freelance marketplace website, Superprof. By using content analysis and quantitative data analysis, the present study has managed to identify 11 categories of information presented in the ads, including tutors' name, origin, current employment status, education background, language proficiency certificate, course level, course type, rhetoric, experience in Japan, coverage area, and availability. Among these 11 categories of information, student tutors and non-student tutors have differences with regard to the inclusion of information related to their current employment status and education background. The avoidance of putting nonstudent tutors' employment status on the ads may be due to the availability of "background" section or the irrelevance of their status with the tuition job. The implication of the study demonstrates that student-tutors tend to value their affiliation with academic institutions and use it as a bargaining power in the hyper-competitive market. Further research should incorporate interviews with the tutors in order to understand the kinds of message or persona they want to deliver to the prospective tutees. Furthermore, the categorization could have been better if assessed by some raters to avoid personal bias (Wang \& Li, 2020).

\section{References}

Andersen, B. (2018). More than just a resume. Mariott Student Review, 2(1), 4751.

Asian Development Bank. (2020). Innovate Indonesia: Unlocking Growth through Technological Transformation (March 2020). Retrieved from http://dx.doi.org/10.22617/SGP200085-2

Cohen, L., Manion, L. \& Morrison, K. (2011). Research Method in Education. 6th ed. London\& New York: Routledge.

Ezzy, D. (2002). Qualitative Analysis: Practice and Innovation. London: Routledge.

Gandini, A. (2016). Digital work: Selfbranding and social capital in the freelance knowledge economy. Marketing Theory, 16(1).

Gere, C. (2008). Digital Culture. London: Reaktion Books Ltd.

Green, D. D., Walker, C., Alabulththim, A., Smith, D., \& Phillips, M. (2018). Fueling the gig economy: a case study evaluation of Upwork.com. Management and Economic Research Journal, 4(2018), 104-112.

Hershatter, A. \& Epstein, M. (2010). Millenials and the world of work: an organization and management perspective. Journal of Business and Psychology, 2010(25), 211-223. Retrieved from http://dx.doi.org/10.1007/s10869-0109160-y 
Krippendorp, K. (2004). Content Analysis: An Introduction to its Methodology. Thousand Oaks, CA: Sage.

Miller, V. (2011). Understanding Digital Culture. London: SAGE Publications Ltd.

Popiel, P. (2017). "Boundaryless" in the creative economy: assessing freelancing on Upwork. Critical Studies in Media Communication, 34(3), 220-233.

PricewaterhouseCoopers. (2011). Millennials at Work: Reshaping the workplace. Retrieved from https://www.pwc.com/co/es/publicaciones/ assets/millennials-at-work.pdf

Rahman, M. S. (2017). The advantages and disadvantages of using qualitative and quantitative approaches and methods in language "testing and assessment" research: a literature review. Journal of Education and Learning, 6(1), 102-112.

"Tentang kami." (n.d.). Superprof. Retrieved from https://www.superprof.co. id/tentang-kami.html

Wang, X. \& Li, X. (2020). The market's expectations of interpreters in China: A content analysis of job ads for in-house interpreters. The Journal of Specialised Translation, 34(July 2020), 118-149.

Woodcock, J. \& Graham, M. (2020). The Gig Economy: A Critical Introduction. Cambridge: Polity Press. 